\title{
A Rose by Any Other Name: Teaching Primary Teachers Citizenship, or PSE, or Social Studies or...
}

Mary Thornton

University of Hertfordshire

\section{Introduction}

What do we mean when we talk of citizenship? Or PSE? Or Social Studies? Or any other name that might be given to teaching and learning about people in society? Osler and Starkey (2000) argue for a holistic approach that incorporates two key and inter-related components, namely the structural/ political and the cultural/ personal. For them

The concept of citizenship is founded on the notion of an individual as actor in a democratic polity and this requires an understanding and acceptance of human rights. ( $p 4)$

At one level this is an acceptable definition, a desired and aimed for notion of UK citizenship with individuals able and willing to act within a democratic, legalised social framework that recognises and incorporates human rights. At another level it is inadequate. There are many citizens of many societies. Are they any less citizens if they act collaboratively or within non-democratic societies? Is not citizenship, with its structural/ political and cultural/ personal dimensions, a wider issue, where diversity reigns, both within and between societies? Is this not part of the concept of citizenship that we seek to understand and explain to our students? In order to understand our own society (or community) and participate in it effectively as citizens, individually or collaboratively, on a global stage, we must surely also study and come to understand alternative systems and their interactions.

As my title suggests I am not much bothered by the labels we attach to learning and teaching about people in society. What does concern me is that all our children, and thus all our teachers, should have a firm grasp of key social issues, concepts and structures. These are the foundations which govern all social interaction, including all aspects of educational provision and educational outcomes. Without such understanding we cannot develop and change our social world, hopefully for the better.

While I remain attached to the notion of social studies precisely because it has the propensity to encompasses all manner of societies and human relationships therein, the emergence of Citizenship Education, as desired and approved curriculum content, enables primary teachers, and teacher educators, to overtly teach about important social issues, not least human rights, justice and democracy (Spencer, 2000).

Margaret Thatcher infamously once said

There is no such thing as society. There are individual men and women, and there are families. (Thatcher, 1987)

If there is no such thing as society then there are no social groups beyond families, no communities, no nations and thus no citizens. Nor is there any need for 'social' education. 
PSE/ Citizenship Education or whatever else one cares to call it was sidelined and suppressed during the educational reforms of the Thatcher years (notably the Education Reform Act, 1988) because it was perceived to be controversial, politically biased, unnecessary. Fortunately it did not expire completely, but we have for the most part let slip through our grasp a generation of teachers for whom PSE/ Citizenship Education was not part of their compulsory teacher training course. Sociologists of Education, who traditionally taught the 'social' curriculum in teacher education, have all but disappeared from the professionally oriented Departments of Education that are ruled by the Teacher Training Agency (TTA). If PSE/ Citizenship is to be revived who will now teach the teachers?

To be fair, following the ERA, the National Curriculum Council did offer guidance on 'Education for Citizenship' (NCC, 1990) as one of five cross-curricula 'themes' that were intended to permeate the newly imposed National Curriculum subjects. But, at a time of overwhelming centrally-imposed change, few training courses found the required space to cover this non-statutory 'thematic' content. Statutory requirements came first and were so substantial that little room was left for what the Thatcher government appeared to perceive to be 'optional frills'.

Times have changed. We now have a labour government, in its second term, that has revived interest in PSE/Citizenship Education. Whilst still not statutory across all phases of compulsory schooling it is for Key Stages 3 and 4, with non-statutory guidance available for Key Stages 1 and 2. It remains to be seen whether this revival will result in the reintegration of PSE/ Citizenship Education into compulsory parts of primary teacher training courses.

\section{The Official Viewpoint: Similarities and Differences}

In 1990 Duncan Graham wrote in his foreword to Education for Citizenship (NCC, 1990) that

Education for citizenship is essential for every pupil. It helps each of them to understand the duties, responsibilities and rights of every citizen and promotes concern for the values by which a civilised society is identified - justice, democracy, respect for the rule of law. (pre p1)

In 1999 David Blunkett (then Secretary of State for Education) and William Stubbs (QCA) wrote a statement of values in their foreword to the non-statutory guidance for KS 1 and 2 (DfEE/QCA, 1999)

Equality of opportunity is one of the broad set of common values and purposes which underpin the school curriculum and the work of schools. These also include a commitment to valuing ourselves, our families and other relationships, the wider groups to which we belong, the diversity in our society and the environment. (p4)

They also wrote that Education in citizenship and democracy will provide coherence in the way in which all pupils are helped to develop a full understanding of their roles and responsibilities as citizens in a modern democracy. It will play an important role... in helping pupils to deal with difficult moral and social questions that arise in their lives and in society. (p4) 
Apart from the earlier emphasis on rights there is very little divergence between the general underlying principles expressed, and rights do appear elsewhere in the 1999 guidance. The major apparent difference is contextual - PSE/ Citizenship Education is now considered important and at least some citizenship education is compulsory (for older pupils).

In the1990 thematic approach there were eight essential components of Citizenship Education

- The nature of community

- Roles and responsibilities in a pluralist society

- The duties, responsibilities and rights of being a citizen

- The family

- Democracy in action

- The citizen and the law

- Work, employment and leisure

- Public services

Now there are four key areas related to knowledge, skills and understanding

- Developing self-confidence and responsibility and making the most of their abilities

- Preparing to play an active role as citizens

- Developing a healthy, safer life-style

- Developing good relationships and respecting the differences between people

The more specific content evident in the 1990 'components' is present in the 1999 framework and its statements of intended teaching. For example the framework states Pupils are encouraged to take part in a wide range of activities... contributing fully to the life of their school and communities...they learn to recognise their own worth, work well with others and become increasingly responsible for their own learning...(they tackle) many of the spiritual, moral, social and cultural issues that are part of growing up. They also find out about the main political and social institutions that affect their lives and about their responsibilities, rights and duties as individuals and members of communities. They learn to understand and respect our common humanity, diversity and differences... (p136)

\section{The Official Viewpoint and the Real World}

As a teacher educator in 1990 I was teaching Year 1 and Year 3 BEd students 'social studies' as part of a 'cluster' of curriculum subjects (Health, Movement and Social Studies). We integrated the subjects and assessment wherever possible but, across the two years, Movement (including gymnastics and games) got sixteen full 3 hour sessions, health got eight and social studies eight. In year 1 the assessment involved the performance of student designed movement sequences that in some way represented a social studies issue that they had learnt about e.g. the division of labour, power and authority, co-operation, interdependence, tradition, social control and social change (ILEA, 1980). This was a difficult task for first years but one they executed well and with some passion and understanding of the social issues that they were portraying through movement. The third year assignment was somewhat less exciting. After social studies input on 'Children's understanding of society', 'Teaching controversial issues', 'Education for citizenship' and 'Cross-curricula 
issues' the student's focused on devising sessions plans for one of the three cluster subjects (student choice).

Social studies survived in this BEd during the early years of the National Curriculum simply because it takes time to rewrite and revalidate courses. At its next revision in 1992 Social Studies as a specific part of the compulsory taught course was dropped in order to better cover the National Curriculum statutory subject content and its assessment requirements. However, it reappeared 1996, in a further revised BEd, in the guise of Comparative Education - another variation of the label PSE/ Citizenship. This is an optional three module 'educational specialism' for third and fourth year students which first came on stream in 1998. They must choose one educational specialism from a list that includes Special Educational Needs, Early Years Education and Monitoring, Assessment, Recording and Reporting. Instead of 24 hours of compulsory social studies students can now opt for 84 hours of Comparative Education. Despite its lack of overt relevance to the statutory requirements of the National Curriculum, in the four years since its inception Comparative Education has proved to be a popular choice, with an average cohort of 20 students.

\section{The Comparative Education Course}

Students opting for Comparative Education as an Educational Specialism are an unusual lot especially given the circumstances of their training. These are students who entered training knowing that they would be required to teach the National Curriculum and especially its 'core' subjects; fully aware of its prescriptiveness in terms of content and recommended teaching methods, its excessive assessment requirements, league tables and general bureaucratic overload. They knuckle down and get on with it. But when the opportunity arises they 'opt out' in favour of something different, perhaps more interesting, and certainly more challenging. They could, after all, chose to specialise in something that has traditionally been perceived to be more important or of higher status e.g. special needs or assessment, and which might be considered more valuable when it comes to first appointments and subsequent promotion. These students continue to 'break the mould' and did so at a time when doing so had no obvious market currency. They are our future teachers and leaders of PSE/ citizenship education in primary schools.

When I ask why they have come and what they expect from the course their answers vary. It is something different they say; they are curious; they want to learn about other education systems in other societies; they want the opportunity to find out about alternatives and to learn from them; to widen their experience; to understand different cultures and expectations; to travel; to do their own research - all things that have been largely absent from TTA-dominated compulsory teacher education courses. They have learnt to sing the prescribed hymns but somehow are aware that there may be other hymns and other ways of singing. These students are brave and free-thinking. They have actively sought out something different, un-prescribed, challenging.

In Year 3 students study one module, titled International Perspectives on Primary Education. From the start they are required to think about, select and individually (or in groups) research into an alternative education system and in particular to focus on one aspect of it e.g. SEN in Sweden, mathematics in Korea, literacy for girls in India, bilingual early years education in New Zealand. Their individual research is prompted and supported by direct input sessions on concepts and methods, internet use, 
literature searching, international comparisons in outcomes and league tables, alternative systems within the UK (e.g. Summerhill, Steiner), research and communication, and workshops where contacts, ideas and developments are shared between peers. They are assessed through a written report on, and presentation to peers of the outcomes of, their research. They must demonstrate background knowledge of the education system studied, some understanding of its cultural and historical context, in depth knowledge and understanding of one aspect of that system, critical reflection on the information they have obtained and the ability to compare and contrast their findings with state provision in England. There is no doubt that some find all this difficult and challenging but none have yet dropped out.

In Year 4 students undertake a double module titled Cross-cultural Comparisons and Education for International Citizenship. The first 3 weeks of the course are blocked out for placements. During this period no other teaching takes place and they are focused purely upon their specialism in Comparative Education. This allows them to be immersed for up to 3 weeks in alternative (i.e. non-UK National Curriculum) educational environments.

While students must self-fund any placements abroad this is still a popular option. This year, of 18 students, four went to the USA, three of whom spent time in an American Indian Reservation School and a Headstart Programme; three went to India to study primary and community education in rural areas; three went to South Africa and gained experience in Africaans and Rural Farm Schools; two have taught English in China; one went to an International School in Switzerland. Those remaining at home (five) visited either Steiner or privately run Progressive Schools, including one student placed at Summerhill.

During these alternative education placements students are required to keep a log of their experiences and reflections. These are then summarised and communicated to their peers through student presentations. The aim is to share as much as possible of this very wide range of experience and new found expertise much of which goes well beyond my own, so I too am continually learning.

Placements are followed by a more traditional taught course that focuses student attention on International Links, Global Citizenship and Human Rights education. We explore a variety of teaching ideas related to diversity, democracy, justice, respect, rights and responsibilities, and work together to turn these alternative educational experiences into meaningful lessons and resources for teaching PSE/ Citizenship Education in English primary schools. Discussions of democracy and school councils take on a whole new dimension when direct experience of the 'tribunal' at Summerhill is available in our classroom; cultural diversity and respect for human rights becomes much more vivid and better understood when some students actually relay their experience of teaching English to Hmong children at the Fond du lac Reservation in Minnesota, or singing songs with black South African children in their Farm School.

Somewhat surprisingly, and totally by accident, this course, designed in 1996, goes a long way to meeting the 1999 non-statutory guidance on Citizenship Education for primary schools (DfEE/QCA, 1999). It develops student teacher confidence and responsibility through the sharing of opinions, exploration of views, the study of 
diversity and common humanity, and active participation - precisely the things the 1999 PSE/Citizenship Guidance requires them to develop in their pupils. It develops student teacher ability to translate their own learning into relevant resources and ideas that will stimulate the children they teach to learn similar things in similar ways. As the Crick Report (QCA, 1998) argued, children cannot simply be taught how to be effective citizens or to have social understanding, they need to learn from experience, to practise and develop the necessary skills. So too their teachers, and this Comparative Education course allows then to do just that.

\section{Should PSE/ Citizenship be statutory in teacher education?}

Yes, I believe it should be but in reality we need much more. The past fifteen years have shown that while statutory requirements ensure something is taught it is not necessarily taught well or with conviction. To teach PSE/ Citizenship well we must instil its underlying philosophy and values into those who will teach it. It must become owned by, and meaningful, to future primary school teachers. This requires much more than the equivalent of a folder of ideas for the Literacy or Numeracy Hour. You cannot teach social justice unless you believe in social justice; you cannot extend the experience and understanding of children unless you extend the experience and understanding of those who teach them. The international and alternative interactions that underpin the Comparative Education course are an effective vehicle through which to develop understanding of society, of human rights, justice and democracy. I believe this course makes such a difference because it goes well beyond mere content issues to do with PSE/Citizenship Education and the fluctuating interest of politicians. It actually effects a change in these students, a value shift that will outlive any curriculum guidance document and have far greater impact upon their teaching.

In the students own words:-

I have thoroughly enjoyed every aspect of the course. I especially enjoyed the alternative education placement and found it fascinating to learn about other education systems. Anyone who has not taken the course has really missed out on a valuable learning experience. During the last few months this has been the one session that I have really looked forward to attending!

I have really enjoyed this course particularly the discussions we have in class.

The alternative placement was fantastic! I learnt so much from it and will use and adapt a lot for use in school. I have really enjoyed this course and especially enjoyed the Save the Children seminars. The only thing that I feel could have been added was maybe a bit more on alternative methods - places we have not been, ideas we have not seen through our experiences.

I would like to have done more! Thank you.

This last term has been very informative generally - stimulating wider thinking.... The order in which the sessions were presented enabled a coherent link to be made with previous knowledge and current research for assignments. An enlightening and enjoyable module.

The course aims are as follows:- 
1. To develop students' analytic and evaluative skills in a comparative context.

2. To understand the inter-relatedness of local and global issues in education.

3. To experience, understand and reflect upon alternative approaches and their underlying philosophies.

4. To widen the experience and perspectives of intending teachers so that they may widen those of the children they teach.

5. To understand and contribute to education's role in promoting international harmony and social justice.

6. To understand the role of research in professional practice.

I cannot claim that all these aims are fully achieved for all students but student evaluations do suggest that its impact is high. At the very least aim four is achieved for all.

\section{Prologue: A rose by any other name......}

Personally I don't much care what the study of society(ies) is called provided that real understanding and critical reflection on first-hand experience of alternative ways of seeing and doing education, and the communities and societies that support those alternatives, forms part of ITE, preferable an essential compulsory part - but that is up to others. The citizenship bandwagon has begun to roll once again. Lets hope it picks up speed and momentum so that all new teachers are trained, and committed to teaching it across the primary school years, and that it ceases to be an 'optional extra'.

Word count 3192

\section{References}

DfEE/QCA (1999) The National Curriculum: handbook for Primary Teachers in England Key Stages 1 and 2, London, HMSO.

ILEA (1980) Social Studies in the Primary School, London, ILEA.

NCC (1990) Curriculum Guidance Eight: Education for Citizenship, York, NCC.

Osler, A.and Starkey, H. (Eds) (2000) Citizenship and Democracy in Schools, Stokeon Trent, Trentham Books.

Qualifications and Curriculum Authority (1998) Education for Citizenship and the Teaching of Democracy in Schools, Crick report, London, QCA.

Spencer, S. (2000) The Implications of the Human Rights Act for Citizenship Education, in Citizenship and Democracy in Schools, Eds. Osler, A.and Starkey, H. Stoke-on Trent, Trentham Books.

Thatcher, M. (1987) in the magazine, Woman's Own (31 October), London. 